\title{
A note on changes in the concentration of short-chain fatty acids in the caecal content of laying hens due to addition of fresh grass to the diet
}

\author{
D. Józefiak ${ }^{1}$ and A. Rutkowski
}

\author{
August Cieszkowski Agricultural University, \\ Department of Animal Nutrition and Feed Management \\ Wotyńska 33, 60-637 Poznań, Poland
}

(Received 20 April 2002; revised version 21 November 2002; accepted 20 December 2002)

\begin{abstract}
Twenty laying hens (Hy Line) kept in individual cages were randomly divided into two groups, B and BG. Both groups were fed a basal diet ad libitum, hens from group BG additionally received $25 \mathrm{~g}$ of fresh chopped grass per day in separate feeders. The experiment lasted twelve days, at the end all birds were slaughtered and the content of the caecum was sampled. Total and individual shortchain fatty acid (SCFA) concentrations in caecal contents were measured by high pressure liquid chromatography. The total amount of SCFA in caecal digesta of hens fed diets with added fresh grass was lower by $27 \%$ in comparison with group $\mathrm{B}(\mathrm{P} \leq 0.05)$, however, the proportions between acetic, propionic and butyric acids were similar in both groups. In both groups the level of acetic acid was highest followed by propionic and butyric acids $(\mathrm{P} \leq 0.05)$.
\end{abstract}

KEYWORDS fresh grass, laying hens, caecal contents, short-chain fatty acids

\section{INTRODUCTION}

Compared with wild birds, the overall length of the gastrointestinal tract in domestic birds is much shorter. Therefore, good performance on commercial poultry farms is dependent on feeding highly digestible diets. However, in recent

\footnotetext{
${ }^{1}$ Corresponding author: Tel/fax (48 61) 8487226; e-mail: damjo@ owl.au.poznan.pl
} 
years increased interest has developed in free-range poultry production (LaszczykLegendre, 1999), where roughage might make up even up to $48 \%$ of a basal diet (Steenfeldt et al., 2001).

There is usually no problem in digestion of most monosaccharides as well as starch in the poultry gastrointestinal tract (GIT). Digestion of NSP fractions, which are the main component of dietary fibre, tends to be more variable due to their heterogeneous nature and lack of susceptibility to poultry digestive enzymes (Carré, 1993; Jamroz et al., 2001).

Dietary fibre is the sum of plant polysaccharides and lignin that are not hydrolysed by endogenous enzymes of the avian and mammalian digestive systems. However, these carbohydrates are hydrolysed by enzymes produced by the avian's GIT microflora. In most poultry species the ceacum is the main site of microbial fermentation (Goldstein, 1989; Pinchasov and Elmaliah, 1994; Vispo and Karasov, 1997; Jamroz et al., 1998). The final products of that process include short-chain fatty acids (SCFA), ammonia, carbon dioxide and methane (Marounek et al., 1999). Organic acids produced during dietary fibre breakdown are similar to those present in the rumen; these include butyric, iso-butyric, acetic, lactic, propionic, valeric and iso-valeric acids (Jamroz et al., 1994).

Diet and age are the main factors influencing fermentation processes (Carré, 1993). Changes of SCFA concentrations in the ceacum due to the amount and type of carbohydrate fractions were observed by many authors in different poultry species (Langhout and Schutte, 1996; Jamroz et al., 1996, 1998; Tsukahara and Ushida, 2000).

However, no data is available about fresh grass as a factor affecting caecal fermentation in laying hens. The objective of this experiment was to determine changes in SCFA concentrations in the caecal content of laying hens fed diets varying in fermentable carbohydrate levels due to addition of the fresh grass.

\section{MATERIAL AND METHODS}

The experiment was done on twenty brown Hy-Line laying hens, 48 weeks old, kept in individual balance cages. Birds were randomly divided into two feeding groups: B and BG. Both groups were fed a basal diet (Table 1) ad libitum, hens from group BG additionally obtained $25 \mathrm{~g}$ per day of fresh chopped grass in separate feeders, which amounted to about $5.5 \%$ of the consumption of the basal diet in group B. Grass was in the mid-maturity stage and consisted of the following species (\%): perennial ryegrass (Lolium perenne L.) 50, red fescue (Festuca rubra L.) 40 and smooth-stalked meadow grass (Poa pratensis L.) 5. The experiment lasted from the 5th to the 17th of May, grass was cut five times a day from randomly chosen parts of a meadow, immediately chopped and offered in separate feeding boxes. 
Composition and nutritional value of basal diet and grass, $\mathrm{g} \cdot \mathrm{kg}^{-1}$ dry matter

\begin{tabular}{|c|c|c|}
\hline Components & \multicolumn{2}{|c|}{ Content } \\
\hline Maize & \multicolumn{2}{|c|}{581.5} \\
\hline Soyabean meal $(46 \% \mathrm{CP})$ & \multicolumn{2}{|c|}{237.0} \\
\hline Rapeseed meal & \multicolumn{2}{|c|}{50.0} \\
\hline Soya oil & \multicolumn{2}{|c|}{20.0} \\
\hline Limestone & \multicolumn{2}{|c|}{80.0} \\
\hline DL-methionine (20\%) & \multicolumn{2}{|c|}{4.0} \\
\hline $\mathrm{NaCl}$ & \multicolumn{2}{|c|}{3.0} \\
\hline Dicalcium phosphate & \multicolumn{2}{|c|}{19.5} \\
\hline Mineral - vitamin premix & \multicolumn{2}{|c|}{5.0} \\
\hline Chemical composition & Basal diet & Grass \\
\hline crude protein $(\mathrm{N} x$ x.25) & 170.9 & 187.1 \\
\hline crude fat & 56.1 & 29.1 \\
\hline crude ash & 149.7 & 109.1 \\
\hline crude fibre & 48.6 & 243.3 \\
\hline monosaccharides & 3.35 & 32.0 \\
\hline starch & 492.5 & 24.4 \\
\hline hemicellulose & 103.1 & 255.2 \\
\hline $\mathrm{NDF}$ & 171.6 & 533.0 \\
\hline $\mathrm{ADF}$ & 68.4 & 277.8 \\
\hline TDF & 127.4 & 618.3 \\
\hline
\end{tabular}

After 12 days of feeding all of the birds were slaughtered by cervical dislocation, the abdominal cavity was opened, and caecal digesta samples were collected for SCFA analysis.

\section{Chemical analysis and calculations}

The chemical composition of the diet and average sample of fresh grass was determined according to AOAC (1990). The content of neutral detergent fibre (NDF) and acid detergent fibre (ADF) was determined according to Van Soest (1963), monosaccharides according to Åman and Graham (1990). The hemicellulose, content was calculated as the difference between NDF and ADF contents. The level of total dietary fibre (TDF) was estimated as dry matter minus crude protein, fat, ash, starch, and monosaccharide contents.

SCFA analysis was conducted by the modified method of Wielen et al. (2000). Approximately $0.4 \mathrm{~g}$ of caecal material was diluted in $1.6 \mathrm{ml}$ of sterile deionized water, mixed, centrifuged for $10 \mathrm{~min}$ at $13,400 \mathrm{x} \mathrm{g}$ and $12.5 \mu \mathrm{l}$ of xylitol solution (internal standard: $0.586 \mathrm{M}$ xylitol in $1.5 \mathrm{M} \mathrm{HCl}$ ) were added to $700 \mu$ l of the sample. Subsequently, samples were again mixed and centrifuged for $10 \mathrm{~min}$ at $13.400 \mathrm{x} \mathrm{g}$ 


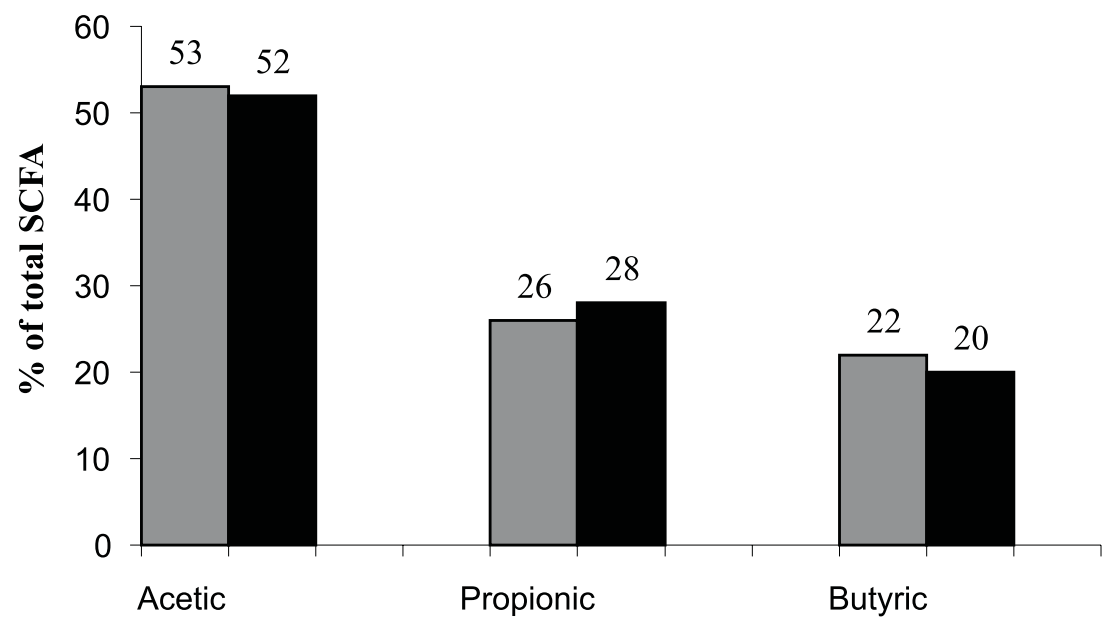

Figure 1. Proportions of acetic, propionic and butyric acids in the caecal contents of laying hens, in $\%$ of total SCFA

before HPLC analysis. Ten microliters of the sample were injected to a HPLC (Waters 2690), equipped with an absorbance detector (Waters 2487) and organic acid column (300x7.8 mm) from Bio-Rad (Animex HPX-87-H Ion exclusion column). The column and auto-sampler were operated at constant temperatures, $35^{\circ} \mathrm{C}$ and $5^{\circ} \mathrm{C}$, respectively. The column was operated with $0.005 \mathrm{M} \mathrm{H}_{2} \mathrm{SO}_{4}$ at $0.6 \mathrm{ml} / \mathrm{min}$ as the eluent, in $95 \mathrm{x}$ $10^{5} \mathrm{~Pa}$. Concentrations of SCFA in caecal samples were compared and calculated with usage of the Volatile Free Acid Standard Mix (46975-U by Supelco).

Statistical analysis was performed using the SAS (1996) System ver. 6.12. Differences were considered significant at $\mathrm{P} \leq 0.05$.

\section{RESULTS AND DISCUSSION}

The following SCFAs were present in caecal digesta samples of laying hens in the present study: acetic, propionic, butyric, iso-butyric, iso-valeric and valeric acids. Jamroz et al. $(1994,1998)$ also found similar SCFAs in caecal digesta in chickens, geese and ducks. In group B acetic, propionic and butyric acids made up 50, 24 and $21 \%$, in group BG, 47, 26 and 17\%, respectively, of the total SCFA amount. Only acetic and butyric acid concentrations differed significantly $(\mathrm{P} \leq 0.05)$ between groups B and BG.

In both groups the acetic acid concentration was markedly higher $(\mathrm{P} \leq 0.05)$ than of the other SCFAs (Figure 1), similarly as reported in chickens, ducks and geese (Jamroz et al. 1994, 1998), in some wild birds (Foley et al., 1989; Grajal et al., 1989; Dawson et al., 2000) and in other monogastric animals (Sunvold et al., 1995). 
TABLE 2

Concentration of short chain fatty acids in caecal content of laying hens, $\mathrm{mMol} / \mathrm{kg}$

\begin{tabular}{llrcccccc}
\hline Group & & Acetic & $\begin{array}{c}\text { Pro- } \\
\text { pionic }\end{array}$ & $\begin{array}{c}\text { n- } \\
\text { butyric }\end{array}$ & $\begin{array}{c}\text { Iso- } \\
\text { butyric }\end{array}$ & $\begin{array}{c}\text { Iso- } \\
\text { valeric }\end{array}$ & Valeric & Total \\
\hline B & Mean & $119.8^{\mathrm{a}}$ & 57.7 & 49.5 & 3.5 & 4.4 & 5.0 & 239.0 \\
& SD & 5.57 & 7.57 & 5.03 & 2.04 & 1.65 & 0.38 & \\
& & & & & & & & \\
BG & Mean & $82.0^{\mathrm{b}}$ & 45.5 & 29.2 & 9.1 & 2.9 & 6.3 & 175.1 \\
& SD & 9.82 & 5.22 & 5.78 & 5.54 & 3.65 & 1.05 &
\end{tabular}

a,b- means in the column with different superscripts are significantly different at $\mathrm{P} \leq 0.05$

SD- standard deviation

The total concentration of SCFAs (Table 2$)$ decreased by $27 \%(\mathrm{P} \leq 0.05)$ after addition of grass, which might be a result of reduced microbial activity, as SCFAs are the main products of microbial fermentation in poultry caeca (Marounek et al., 1999). No significant changes in the mutual proportions of acetic, propionic and butyric acids were observed (Table 2), which may indicate that caecal microflora had altered activity, while interactions between populations were stable. Probably caecal microorganisms of laying hens, similarly as in ruminants, need a longer time to adapt to a new type of diet.

Microbial activity in the caeca of geese, galliforms and ratites (other than the emu) is primarily fermentative (Vispo and Karasov, 1997) and SCFA concentrations are relatively high. However, the total SCFA concentration found in caecal digesta of laying hens in the present study was much higher compared with levels found in the caecal digesta of geese or ducks (Jamroz et al., 1998) fed a triticale-based diet. The literature about changes of caecal microflora and SCFA concentrations in laying hens is limited and more experiments with longer periods of feeding grass are needed.

\section{CONCLUSIONS}

Individual short-chain fatty acids found in the caecal content of laying hens were similar to those observed in other domestic and wild avian species, however, their total concentrations were higher. Addition of fresh grass to the diet affected caecal fermentation processes, resulting in lower total SCFA concentration, without changing the mutual proportions of acetic, propionic and butyric acids. 


\section{SHORT-CHAIN FATTY ACIDS IN THE CAECAL CONTENT OF HENS}

\section{REFERENCES}

AOAC, 1990. Association of Official Analytical Chemists, Official Methods of Analysis. 15th Edition. Arlington, VA

Åman P., Graham H., 1990. Chemical evaluation of polysaccharides in animal feeds. In: J. Wiesman, D.J. Cole (Editors). A Feedstuff Evaluation. Butterworths, London, pp.161-177

Carré B., 1993. Digestibility of carbohydrates in poultry. Proceedings of $9^{\text {th }}$ European Symposium on Poultry Nutrition, Jelenia Góra (Poland), pp. 148-163

Dawson T.J., Whitehead P.J., McLean A., Fanning F.D., Dawson W.R., 2000. Digestive function in Australian magpie geese (Anseranas semipalmata). Aust. J. Zool. 48, 265-279

Foley W.J., Hume I.D., Cork S.J., 1989. Fermentation in the hindgut of the great gilder (Petauroides volans) and brushtail possum (Trichosurus vulpecula) two arboreal folivores. Physiol. Zool. $62,126-43$

Goldstein D.L., 1989. Absorption by the cecum of wild birds: is there interspecific variation. J. Exp. Zool. Suppl. 3, 103-10

Grajal A., Strahl S.D., Parra R., Dominguetez M.G., Heher A., 1989. Foregut fermentation in the hoatzin, a neotropical leaf-eating bird. Science 245, 1236-1238

Jamroz D., Jakobsen K., Orda J., Skorupińska J., Wiliczkiewicz A., 2001. Development of the gastrointestinal tract and digestibility of dietary fibre and amino acids in young chickens, ducks and geese fed diets with high amounts of barley. Comp. Biochem. Physiol. Pt A 130, 643-652

Jamroz D., Wiliczkiewicz A., Skorupińska J., 1998. Fermentation and apparent digestion of the structural carbohydrates in chicks, ducks and geese fed triticale mixtures supplemented with enzymes (in German). J. Anim. Physiol. Anim. Nutr. 79, 1-17

Jamroz D., Wiliczkiewicz A., Orda J., Skorupińska J., 1994. Ileal and postileal fermentation of cereal carbohydrates in chicken and ducks (in German). Wien. Tierärztl. Monatsschr. 81, 80-84

Langhout D.J., Schutte J.B., 1996. Nutritional implications of pectins in chicks in relation to esterification and origin of pectins. Poultry Sci. 75, 1236-1242

Laszczyk-Legendre A., 1999. Label rouge traditional free range poultry: a concept including quality, environment and welfare. Proceedings 14th European Symposium on the Quality of Poultry Meat, Bologna, Vol. I, 255-265

Marounek M., Suchorska O., Savka O., 1999. Effect of substrate and feed antibiotics on in vitro production of volatile fatty acids and methane in caecal contents of chickens. Anim. Feed Sci. Tech. 80, 223-230

Pinchasov Y., Elmaliah S., 1994. Broiler chick responses to anorectic agents: 1. Dietary acetic and proponic acids and the digestive system. Poultry Sci. 73, 648-652

Sunvold G.D., Hussein H.S., Fahey G.C. Jr., Merchen N.R., Reinhart G.A., 1995. In vitro fermentation of cellulose, beet pulp, citrus pulp and citrus pectin using fecal inoculum from cats, dogs, horses, humans and pigs and ruminal fluid from cattle. J. Anim. Sci. 73, 3639-3648

Steenfeldt S., Engberg, R.M., Kjaer J.B., 2001. Feeding roughage to laying hens affect egg production, gastrointestinal parameters and mortality. Proceedings of $13^{\text {th }}$ European Symposium on Poultry Nutrition, Blankenberge (Belgium), pp. 238-239

Tsukahara T., Ushida K., 2000. Effects of animal or plant protein diets on caecal fermentation in guinea pigs (Cavia porcellus), rats (Rattus norvegicus) and chicks (Gallus gallus domesticus). Comp. Biochem. Physiol. Pt. A 127, 139-146

Van Soest P.J., 1963. Use of detergents in the analysis of fibrous feeds. II. A rapid method of the determination of fibre and lignin. J. Assn. Agr. Chem. 46, 829-835 
Vispo C., Karasov W.H., 1997. The interaction of avian gut microbes and their host: an elusive symbiosis. In: R. Mackie, B.A. White (Editors). Gastrointestinal Microbiology. Vol. 1. Gastrointestinal Ecosystems and Fermentations. Chapman and Hall Microbiology Series, pp. 116-156

Wielen van der P.W., Biesterveld S., Notermans S., Hofstra H., Urlings B.A.P., van Knapen F., 2000. Role of volatile fatty acids in development of the caecal microflora in broiler chickens during growth. Appl. Environ. Microbiol. 66, 2536-2540

\section{STRESZCZENIE}

\section{Wpływ dodatku trawy do diety na koncentrację krótkolańcuchowych kwasów tluszczowych w treści jelit ślepych kur niosek}

Dwadzieścia kur niosek (Hy Line) podzielono losowo na dwie grupy: B i BG. Przez dwanaście dni ptaki obydwóch grup otrzymywały dietę podstawową do woli, w grupie BG dodatkowo w oddzielnych karmidłach świeżą, pociętą trawę w ilości $25 \mathrm{~g} /$ ptak/dzień. W 12 dniu doświadczenia wszystkie ptaki ubito i pobrano treść jelit ślepych. W treści jelit ślepych oznaczono stężenie krótkołańcuchowych kwasów tłuszczowych. W grupie otrzymującej dodatek trawy stężenie krótkołańcuchowych kwasów tłuszczowych w treści jelit ślepych było niższe o $27 \%$ w porównaniu z grupą $\mathrm{B}(\mathrm{P} \leq 0,05)$, jednak proporcje między kwasami: octowym, propionowym i masłowym nie zmieniły się istotnie. $\mathrm{W}$ treści jelit ślepych w obydwóch grupach największe było stężenie kwasu octowego, następnie propionowego i masłowego $(\mathrm{P} \leq 0,05)$. 